\title{
In situ calibration of fura-2 and BCECF fluorescence in adult rat ventricular myocytes
}

\author{
STEVEN BORZAK, RALPH A. KELLY, BERNHARD K. KRÄMER, \\ YOSHIKI MATOBA, JAMES D. MARSH, AND MARTIN REERS \\ Cardiology Division, Departments of Medicine, Brigham and Women's Hospital \\ and Harvard Medical School, Boston, Massachusetts 02115
}

Borzak, Steven, Ralph A. Kelly, Bernhard K. KräMER, Yoshiki Matoba, JAMES D. MARSH, AND MARTIN REERS. In situ calibration of fura-2 and BCECF fluorescence in adult rat ventricular myocytes. Am. J. Physiol. 259 (Heart Circ. Physiol. 28): H973-H981, 1990.-Quantitation of $\mathrm{Ca}^{+}$and $\mathrm{H}^{+}$ activities within cells using presently available fluorescent probes is optimal when the fluorescence signal is calibrated in situ after each experiment. Fura-2 and $2^{\prime}, 7^{\prime}$-bis(2-carboxyethyl)-5,6-carboxyfluoroscein (BCECF) are difficult to calibrate in freshly dissociated adult cardiac myocytes because calibration procedures produce cellular hypercontracture. In situ calibration was accomplished in rat ventricular cells by saturating fura-2 with $\mathrm{La}^{3+}$, an agent known to produce myocardial relaxation. Since fura-2 has different spectral properties when complexed with $\mathrm{La}^{3+}$ than with $\mathrm{Ca}^{2+}$, scaling factors were defined in vitro and then verified by experiments in cultured neonatal myocytes. In adult rat myocytes using the $\mathrm{La}^{3+}$ method, intracellular $\mathrm{Ca}^{2+}$ concentration $\left(\left[\mathrm{Ca}^{2+}\right]_{\mathrm{i}}\right)$ was $131 \pm$ $47 \mathrm{nM}(n=14)$ in quiescent cells; diastolic $\left[\mathrm{Ca}^{2+}\right]_{\mathrm{i}}$ and systolic $\left[\mathrm{Ca}^{2+}\right]_{\mathrm{i}}$ in myocytes stimulated at $1 \mathrm{~Hz}$ were $140 \pm 56$ and 1,088 $\pm 211 \mathrm{nM}(n=5)$, respectively. BCECF fluorescence was calibrated in situ by a method that prevented cellular hypercontracture and reported a pH value of $7.10 \pm 0.10$ in cells stimulated at $1.5 \mathrm{~Hz}$. An additional advantage of both methods is that the buffers employed prevented large changes in the redox state of intracellular pyridine nucleotides, thus preventing a change in cellular autofluorescence during the calibration procedure.

$2^{\prime}, 7^{\prime}$-bis (2-carboxyethyl)-5,6-carboxyfluoroscein; lanthanum; calcium

ACCURATE METHODs for measuring intracellular $\mathrm{Ca}^{2+}$ concentration $\left(\left[\mathrm{Ca}^{2+}\right]_{\mathrm{i}}\right)$ and intracellular $\mathrm{pH}\left(\mathrm{pH}_{\mathrm{i}}\right)$ in living cells have long been sought. Among the many requirements for an ideal technique is the precise and reproducible calibration of the measurement device, preferably in the cell or system being measured and under the same conditions as the preceding experiment. Fluorescent ion-selective dyes introduced into living cells and calibrated in situ offer this potential advantage. However, since the advent of second-generation fluorescent dyes for measuring cytosolic free $\mathrm{Ca}^{2+}$ (fura-2 and indo-1) (12) and $\mathrm{H}^{+}$concentrations $\left[2^{\prime}, 7^{\prime}\right.$-bis $(2$-carboxyethyl)-5, 6-carboxyfluorescein (BCECF)] (6), calibration of their fluorescent signals in cells have been hampered by many methodological limitations (21). Despite the advantages of ratio spectroscopy (6), problems such as photobleaching $(6,24)$ and uncertainty about dye ion binding and spectral behavior in the intracellular environment (15) have prohibited confident assignment of $\left[\mathrm{Ca}^{2+}\right]_{\mathrm{i}}$ values to fluorescence signals. Although introduction of dye into cells in membrane-permeant [acetoxymethylester (AM) form] obviates the need for cell impalement, the additional problems of compartmentation of dye into intracellular organelles $(21,28,29)$ and incomplete hydrolysis of ester groups leaving fluorescent but $\mathrm{Ca}^{2+}$-insensitive intermediates $(20,25)$ have further confounded calibration.

Additional problems are encountered when calibration of $\mathrm{Ca}^{2+}$-sensitive dyes in heart cells is attempted (10). Spectral interference by fluorescent cellular components such as NAD(P)H (16; K. Esumi, T. W. Smith, and J. D. Marsh, unpublished observations) can occur. If pyridine nucleotide fluorescence changes during the course of an experiment, incorrect estimates of the cellular contribution to autofluorescence could lead to errors in assigning $\mathrm{Ca}^{2+}$ values to fluorescence signals. Furthermore, freshly dissociated adult cells hypercontract when $\left[\mathrm{Ca}^{2+}\right]_{\mathrm{i}}$ approaches levels sufficient to saturate fura-2 during calibration procedures (18). Hypercontracture can, among other problems, lead to altered fluorescence due to the cell changing shape and losing membrane integrity (9) and has thus been a major impediment to reliable in situ calibration.

We report a novel approach for calibrating the $\mathrm{Ca}^{2+}$ sensitive dye fura- 2 and the $\mathrm{pH}$-sensitive dye BCECF in adult rat ventricular cells using methods that prevent the hypercontracture into square and round forms frequently seen with this model. For fura-2, the ability of $\mathrm{La}^{3+}$ to relax cardiac myocytes and produce fluorescence changes in $\mathrm{Ca}^{2+}$-sensitive indicators (22) has been exploited. The in vitro spectra of $\mathrm{Ca}^{2+}$ - and $\mathrm{La}^{3+}$-bound fura-2 were compared to define the relationship between fluorescence intensity and each ion concentration. $\mathrm{La}^{3+}$ 
was then substituted for $\mathrm{Ca}^{2+}$ in a calibration scheme that allows an accurate determination of ion-saturated fura-2 fluorescence under conditions where both cell shape and energy status are preserved. In the case of BCECF, a buffer that prevents shape change and obviates related artifacts has been devised.

\section{MATERIALS AND METHODS}

Fluorescence measurements. All measurements were performed in a Spex CM2 dual excitation spectrofluorimeter (Spex Industries, Edison, NJ). Fura-2-La ${ }^{3+}$ and fura-2- $\mathrm{Ca}^{2+}$ spectra were obtained in a quartz cuvette placed in a thermostatically controlled mount (rightangle mode) that maintained temperature at $37^{\circ} \mathrm{C}$ with continuous stirring. For fluorescence measurements in isolated and cultured cells, the cuvette was removed and excitation light was allowed to pass through the cuvette chamber into the rear port of an inverted epifluorescence microscope (Nikon Diaphot-TMD, Secaucus, NJ) specially fitted for ultraviolet wavelengths (Nikon CFFluorDL $\times 40,0.85$-NA lens). A dichroic mirror suitable for the specific fluorophore (400-nm cutoff for fura-2, 510-nm cutoff for BCECF) reflected the emission light toward the side port and into a custom-built spectral separator (Rincon Industries, Santa Barbara, CA) that contained a dichroic mirror (600-nm cutoff), band-pass filter $(500 \pm 5 \mathrm{~nm}$ for fura-2, $530 \pm 5 \mathrm{~nm}$ for BCECF, Andover, Salem, NH) positioned before a photomultiplier tube (Hamamatsu R268UH), and a CCD videocamera (Pulnix TM 540/560, Sunnyvale, CA), the light path of which was at a right angle to the photomultiplier. The configuration of the spectral separator allowed red phase-contrast illumination of the cell to be separated from the near-ultraviolet fluorescence of the fura-2 or $\mathrm{BCECF}$, so that the cell image could be monitored continuously throughout the experiment on a television monitor (Panasonic WV 5470, Garden City, NJ) and recorded on videotape (Sony SL-HF360). The video image was also directed to a motion detector (Crescent Electronics, Sandy, UT) with time resolution of $16.7 \mathrm{~ms}$ so that the position of the edge of the cell during phasic or tonic contractions could be recorded on a chart recorder (Gould 2200, Cleveland, $\mathrm{OH}$ ). An adjustable aperture positioned between the spectral separator and the microscope allowed adjustment of the field size to just include a single cell; thus background fluorescence could vary between experiments. Cover slips with attached cells were placed in a water-jacketed chamber (37 \pm $0.5^{\circ} \mathrm{C}$ ) on the light-shielded stage of the microscope. Cells were continually superfused with buffer at a rate of 1 $\mathrm{ml} / \mathrm{min}$. Cells were field stimulated at variable rates with a 3-ms square-wave pulse delivered through a platinum electrode connected to a stimulator (Grass model S44, Quincy, MA). Only one experiment per cover slip was performed.

For experiments in both the cuvette and microscope, exposure to excitation light was limited to the time of actual data collection by an electronically controlled shutter. In addition, to limit photobleaching, a neutral density filter (0.1 transmittance for BCECF, 0.5 for fura2 , Andover) was placed in the excitation light path.
Excitation wavelengths were selected from a $450-W$ xenon lamp by adjustable diffraction gratings and alternated by a four-position rotating chopper wheel, the speed of which was controlled by computer and dictated by the chosen times of data accrual. For fura-2, excitation wavelengths were 340 and $380 \mathrm{~nm}$, and for BCECF, 490 and $450 \mathrm{~nm}$. The bandwidth in all cases was $3.6 \mathrm{~nm}$. Fluorescence signals were normalized to lamp intensity by a rhodamine reference standard.

For recording $\left[\mathrm{Ca}^{2+}\right]_{\mathrm{i}}$ transients, fluorescence emission was collected from 340 - and 380 -nm excitation over $1 \mathrm{~ms}$ at each wavelength, with $1 \mathrm{~ms}$ required for repositioning the chopper. Photon counts from each wavelength were then assigned to the same time value with an increment every $3 \mathrm{~ms}$, the effective time resolution. No averaging of beats or continuous measurements at single wavelengths were made. $\left[\mathrm{Ca}^{2+}\right]_{\mathrm{i}}$ was determined in situ in each cell utilizing Eqs. 1-3 below. [ $\left.\mathrm{Ca}^{2+}\right]_{\mathrm{i}}$ transients were then low-pass filtered at $100 \mathrm{~Hz}$ by data analysis software (ASYST, Macmillan Software, New York, NY) to decrease high-frequency noise. For fluorescence recording during calibration protocols, data were collected every 3 $\mathrm{s}$ and not filtered.

Fura-2 excitation spectra. Excitation spectra for fura2 and both $\mathrm{Ca}^{2+}$ and $\mathrm{La}^{3+}$ were obtained in a quartz cuvette with $10 \mu \mathrm{M}$ fura-2 pentapotassium salt (Molecular Probes, Eugene, OR) in a buffer consisting of (in $\mathrm{mM}) 110 \mathrm{KCl}, 203-(N$-morpholino)propanesulfonic acid (MOPS), $1.0 \mathrm{MgCl}_{2}$, and sucrose-mannitol (3:1) in sufficient quantity to reach an osmolality of $300 \mathrm{mosmol} /$ $\mathrm{kg}$ as determined by an osmometer (Wescor). Buffer was passed through an anion exchange column (Amberlite MB-3, Sigma, St. Louis, MO) to reduce $\left[\mathrm{Ca}^{2+}\right]_{\mathrm{i}}$ to $\sim 1 \mu \mathrm{M}$ as determined by $\mathrm{Ca}^{2+}$-sensitive electrode (Orion, Cambridge, MA). $\mathrm{CaCl}_{2}$ (100 $\mathrm{mM}$ standard reference solution, Orion), $\mathrm{MnCl}_{2}$, and $\mathrm{LaCl}_{3}$ (Sigma, $100 \mathrm{mM}$ stock solutions) were added directly to the cuvette and spectra were measured. 2,3-Butanedionemonoxime (BDM, Sigma) was added to the cuvette as a solid. $\mathrm{pH}$ was regulated by the addition of $\mathrm{KOH}$ or $\mathrm{HCl}$ and monitored between spectra and adjusted when necessary after any addition to the cuvette.

Preparation and dye loading of adult ventricular cells. $\mathrm{Ca}^{2+}$-tolerant ventricular cells were enzymatically isolated from the hearts of adult female Sprague-Dawley rats (250-350 g, Charles River) by methods previously described (13). Briefly, hearts were perfused with a Krebs-Henseleit bicarbonate buffer containing nominally zero $\mathrm{Ca}^{2+}$, collagenase, and hyaluronidase. Ventricles were minced and incubated in the same buffer containing trypsin and $1 \mathrm{mM} \mathrm{CaCl}_{2}$, and cells were released by trituration and sedimentation in $2 \%$ bovine serum albumin. Cells were stored at $23^{\circ} \mathrm{C}$ for up to $4 \mathrm{~h}$ in superfusion buffer with the following composition (in $\mathrm{mM})$ : 4-N-2-hydroxyethylpiperazine- $N^{\prime}$-2-ethanesulfonic acid (HEPES), $137 \mathrm{NaCl}, 0.9 \mathrm{CaCl}_{2}, 0.5 \mathrm{MgCl}_{2}$, and 5.6 glucose, $\mathrm{pH} 7.4$ with $\mathrm{NaOH}$ at $37^{\circ} \mathrm{C}$.

Cells were loaded with fura-2/AM by incubating $2 \mathrm{ml}$ of cell suspension $\left(\sim 5 \times 10^{4}\right.$ cells $\left./ \mathrm{ml}\right)$ with $0.1 \mathrm{ml}$ of fura stock solution (final fura-2/AM concentration, $4.8 \mu \mathrm{M}$ ) for $5 \mathrm{~min}$ at $23^{\circ} \mathrm{C}$ and then washed and attached to glass 
cover slips coated with liquid collagen (Vitrogen, Collagen, Palo Alto, CA) and stored in the dark until use. Fura-2 stock solution was prepared by mixing $0.5 \mathrm{ml}$ of $1 \mathrm{mM}$ fura-2/AM (Molecular Probes) reconstituted in dry dimethyl sulfoxide (DMSO) with $0.1 \mathrm{ml} 25 \%$ (wt/wt) Pluronic F127 in DMSO (Molecular Probes) and $4.4 \mathrm{ml}$ fetal calf serum (FCS). The mixture was sonicated and then stored at $-70^{\circ} \mathrm{C}$ in aliquots until ready for use.

Cells were loaded with BCECF by first permitting cell attachment to collagen-coated cover slips and then incubating the cover slips in superfusion buffer with $2 \mu \mathrm{M}$ $\mathrm{BCFCF} / \mathrm{AM}$ (Molecular Probes) for $30 \mathrm{~min}$ at $23^{\circ} \mathrm{C}$ followed by washing. BCECF/AM stock solution was prepared in dry DMSO at $1 \mathrm{mM}$ concentration and kept frozen in aliquots until use.

Culture and dye loading of neonatal ventricular cells. Primary cultures from ventricles of 1-day-old SpragueDawley rats (Charles River) were prepared by a modification of previously described methods (4). Briefly, ventricles were removed from ether-anesthetized rats and minced, and cells were dispersed in $0.25 \%$ trypsin (GIBCO) with $1 \mathrm{mM}$ EDTA. Cell suspensions were washed in Dulbecco's modified Eagle's medium (DMEM) supplemented with $10 \%$ FCS and antibiotics $(20 \mathrm{U} / \mathrm{ml}$ penicillin, $20 \mu \mathrm{g} / \mathrm{ml}$ streptomycin and gentamicin) and enriched with myocytes by preplating on 100 -mm culture dishes for $1 \mathrm{~h}$ at $37^{\circ} \mathrm{C}$. Residual unattached cells were diluted with the same medium and layered on $12-\mathrm{mm}$ circular glass cover slips in 24-well clusters at a density of $4 \times 10^{5}$ cells $/ \mathrm{cm}^{2}$. The medium was changed on day 1 to DMEM with $7 \%$ FCS and thymidine $(600 \mu \mathrm{g} / \mathrm{ml})$ and on day 2 to DMEM with insulin $(5 \mu \mathrm{g} / \mathrm{ml})$, transferrin $(5 \mu \mathrm{g} / \mathrm{ml})$, and selenium $(5 \mathrm{ng} / \mathrm{ml})$ in the absence of FCS. Cells were used for experiments after 1 or 2 days incubation in serum-free medium.

Cells were loaded with fura-2/AM by replacing incubation medium with $0.1 \mathrm{ml}$ fura-2 stock solution as formulated above in $2 \mathrm{ml}$ of HEPES-buffered superfusion medium for $20 \mathrm{~min}$ at $37^{\circ} \mathrm{C}$. Cover slips with attached cells were washed and stored in the dark at $37^{\circ} \mathrm{C}$ in superfusion buffer until use.

Fura-2 calibration in cells. Calibration was performed in quiescent adult ventricular cells without stimulation and with stimulation at $1 \mathrm{~Hz}$ in cultured neonatal cells. Adult myocytes were individually calibrated in situ by sequential exposure to calibration buffers as follows: $I$, standard superfusion buffer with substitution of $1 \mathrm{mM}$ ethylene glycol-bis( $\beta$-aminoethyl ether)- $N, N, N^{\prime}, N^{\prime}$-tetraacetic acid (EGTA) for $\mathrm{CaCl}_{2}$ and the addition of 5 $\mathrm{mM}$ pyruvate for $30 \mathrm{~s}$; II, buffer I with $10 \mu \mathrm{M}$ ionomycin for at least $5 \mathrm{~min}$ until a stable minimum signal was achieved; and III, buffer II with the substitution of $1 \mathrm{mM}$ $\mathrm{LaCl}_{3}$ for EGTA for 2-3 min or until a stable maximum was achieved. This process resulted in no change in cell morphology as observed on the videomonitor.

Cultured neonatal cells were calibrated in situ identically, except that cation-saturated fura-2 fluorescence was determined twice, first with buffer III containing 1 $\mathrm{mM} \mathrm{CaCl}{ }_{2}$ instead of $\mathrm{LaCl}_{3}$ and then buffer III containing $\mathrm{LaCl}_{3}$. Background fluorescence in both cell systems was determined by measuring fluorescence from an adjacent cell-free area of the cover slip; values for each excitation wavelength were subtracted from the entire recording. $\left[\mathrm{Ca}^{2+}\right]_{\mathrm{i}}$ was determined by the equation of Grynkiewicz et al. (12)

$$
\left[\mathrm{Ca}^{2+}\right]_{\mathrm{i}}=K_{\mathrm{d}} \times \beta\left(\mathrm{R}-\mathrm{R}_{\text {min }}\right) /\left(\mathrm{R}_{\max }-\mathrm{R}\right)
$$

where $K_{\mathrm{d}}$ is the dissociation constant for fura-2-Ca ${ }^{2+}$ and taken to be $224 \mathrm{nM}(9,12), \beta$ is the "scaling factor" defined as the ratio of fluorescence at $380 \mathrm{~nm}$ with 0 $\mathrm{Ca}^{2+}\left(F_{380 \text { min }}\right)$ to saturating $\mathrm{Ca}^{2+}\left(F_{380 \text { max }}\right)$ conditions, and $\mathrm{R}$ is the ratio of fluorescence obtained with excitation at 340 and $380 \mathrm{~nm}$, with min and max subscripts denoting the ratios obtained under $\mathrm{Ca}^{2+}$-free and $\mathrm{Ca}^{2+}$-saturating conditions, respectively. To account for the fact that in our system, maximum fluorescence was obtained with $\mathrm{La}^{3+}$ rather than $\mathrm{Ca}^{2+}, E q .1$ was substituted with the following equations defining two correction factors

$$
\begin{aligned}
\mathrm{R}_{\text {max }, \mathrm{Ca}} & =C_{1} \times \mathrm{R}_{\text {max }, \mathrm{La}} \\
F_{380 \max , \mathrm{Ca}} & =C_{2} \times F_{380 \text { max }, \mathrm{L} a}
\end{aligned}
$$

where $R_{\text {max,Ca }}$ and $R_{\text {max,La }}$ are the ratios of fluorescence at 340 and $380 \mathrm{~nm}$ obtained under saturating conditions of $\mathrm{Ca}^{2+}$ and $\mathrm{La}^{3+}$, respectively; $F_{380 \mathrm{max}, \mathrm{Ca}}$ and $F_{380 \mathrm{max}, \mathrm{La}}$ are the fluorescence values obtained at $380 \mathrm{~nm}$ under saturating conditions of $\mathrm{Ca}^{2+}$ and $\mathrm{La}^{3+}$, respectively; and $C_{1}$ and $C_{2}$ are the correction factors obtained from cuvette experiments as described below.

We compared this calibration approach to two other published methods for in situ calibration of fura-2 fluorescence. For the first alternative method, cells were superfused with nominally $\mathrm{Ca}^{2+}$-free standard HEPES buffer containing $40 \mathrm{mM} \mathrm{BDM}$, followed by the same buffer with the addition of $1 \mathrm{mM}$ EGTA and $10 \mu \mathrm{M}$ ionomycin, and finally an identical buffer with $1 \mathrm{mM}$ $\mathrm{Ca}^{2+}$ substituted for EGTA (9). For the second alternative method, cells were "deenergized" by superfusion with glucose-free HEPES buffer containing $3.3 \mathrm{mM}$ amobarbital (Amytal) and $2 \mu \mathrm{M}$ carbonyl cyanide $m$-chlorophenylhydrazone (CCCP) until the cell shortened to 60 $70 \%$ of resting length $(\sim 5 \mathrm{~min})(18)$. The cell was then exposed to buffer containing 0 glucose, $1 \mathrm{mM} \mathrm{Ca}^{2+}$, and $10 \mu \mathrm{M}$ ionomycin and finally to an identical buffer with 1 mM EGTA substituted for $\mathrm{Ca}^{2+}$.

$B C E C F$ calibration in adult ventricular myocytes. Each cell was individually calibrated in situ (6). Cells were stimulated at $1.5 \mathrm{~Hz}$ until superfusion with EGTA (buffer I). After $30 \mathrm{~s}$ of superfusion with buffer I, II or III calibration buffers with differing $\mathrm{pH}$ were superfused for 2-3 min each until a steady fluorescence signal was achieved. Background fluorescence was determined from the blank cover slip and subtracted from fluorescence at each wavelength. This calibration method produced no change in cell shape. Calibration buffers differed from the superfusion medium and contained $4 \mathrm{mM}$ HEPES$\mathrm{KOH}, 120 \mathrm{mM} \mathrm{KCl}, 0.5 \mathrm{mM}$ EGTA, $5 \mathrm{mM}$ pyruvate, 5.6 $\mathrm{mM}$ glucose, $10 \mathrm{mM}$ ATP-K, and the ionophores $20 \mu \mathrm{M}$ nigericin, $4 \mu \mathrm{M}$ ionomycin, and $0.2 \mu \mathrm{M}$ CCCP. $\mathrm{pH}$ was adjusted at $37^{\circ} \mathrm{C}$ with $\mathrm{KOH}$ or $\mathrm{HCl}$ to $6.54,7.27$, and 7.75. $\mathrm{pH}_{\mathrm{i}}$ for each cell was then determined from a linear regression of fluorescence ratio vs. the $\mathrm{pH}$ values of the calibration buffers. 
Compartmentation studies. Adult myocytes loaded with fura-2 or BCECF were chemically skinned by superfusion with a buffer that permeabilized the sarcolemmal membrane but left organelles intact and the cell shape well preserved $(2,28)$. This buffer was identical to that used for determination of $\mathrm{Ca}^{2+}$ and $\mathrm{La}^{3+}$ spectra with the addition of $1 \mathrm{mM}$ EGTA, $1 \mathrm{mM} \mathrm{KH} \mathrm{PO}_{4}-\mathrm{K}_{2} \mathrm{HPO}_{4}, 10$ $\mathrm{mM}$ succinate, $1 \mu \mathrm{M}$ rotenone, $10 \mathrm{mM}$ ATP-K, and 10 $\mu \mathrm{M}$ digitonin. After release of fura- 2 from the cytosol, superfusion was continued with the same buffer plus 1 $\mathrm{mM} \mathrm{Mn}{ }^{2+}$ and $10 \mu \mathrm{M}$ ionomycin to quench fluorescence from residual fura-2 within organelles. Calculations were made from fluorescence monitored at $359 \pm 1.8 \mathrm{~nm}$ for fura-2-loaded cells (the isosbestic wavelength) and at 450 $\pm 1.8 \mathrm{~nm}$ in BCECF-loaded cells $(\mathrm{pH}$ insensitive and nearly isosbestic).

Statistical analysis. Results are expressed as means \pm SD. Linear regression analysis was performed by standard formulas. Means were compared with one-way analysis of variance for repeated measures.

\section{RESULTS}

Fura-2 spectra and calculation of $\mathrm{La}^{3+}$ calibration constants. Figure 1 shows excitation spectra for fura-2 salt after additions of $\mathrm{Ca}^{2+}, \mathrm{Mn}^{2+}$, and $\mathrm{La}^{3+}$. $\mathrm{La}^{3+}$ fluorescence was hyperchromic at $340 \mathrm{~nm}$ and hypochromic at 380 nm relative to $\mathrm{Ca}^{2+}$; this was observed regardless of whether $\mathrm{La}^{3+}$ or $\mathrm{Ca}^{2+}$ was first added to the cuvette. Increasing $\left[\mathrm{La}^{3+}\right]$ to $>10 \mu \mathrm{M}$ had no effect on fura-2$\mathrm{La}^{3+}$ spectra. The peak fluorescence intensity observed with $\mathrm{La}^{3+}$ occurred at $332 \mathrm{~nm}$, compared with $338 \mathrm{~nm}$ seen with $\mathrm{Ca}^{2+}$, in accord with a similar observation for the indo-1- $\mathrm{La}^{3+}$ spectra (22). $\mathrm{Mn}^{2+}$ quenched fura-2-La ${ }^{3+}$ fluorescence $\sim 25 \%$ when present in 10 -fold molar excess; equimolar addition of $\mathrm{Mn}^{2+}$ to fura-2- $\mathrm{Ca}^{2+}$ quenched fluorescence completely.

Analysis of these spectra allowed the calculation of the ratio of fluorescence at 340 to $380 \mathrm{~nm}$ under saturating $\left[\mathrm{Ca}^{2+}\right](0.9 \mathrm{mM})$ and $\left[\mathrm{La}^{3+}\right](1 \mathrm{mM})$ conditions (Table 1 ). The ratios were relatively insensitive to changes in $\mathrm{pH}$, although fura-2-La ${ }^{3+}$ spectra were more affected

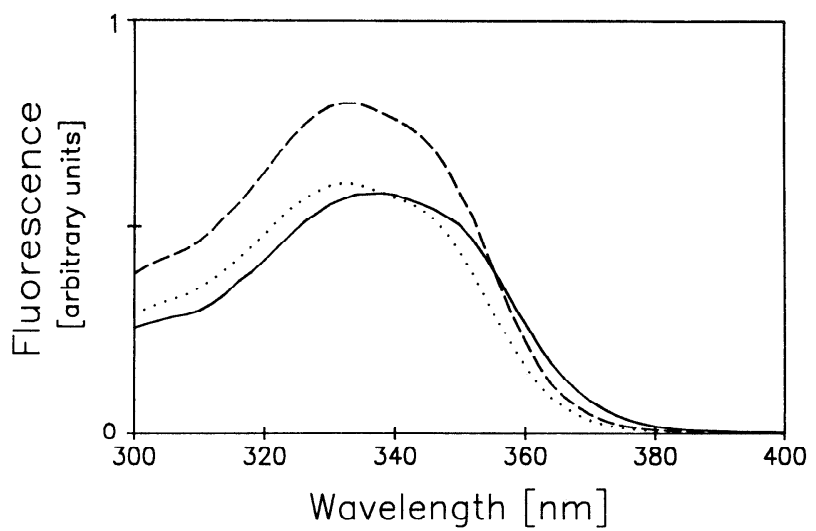

FIG. 1. Excitation spectra of fura-2-Ca ${ }^{2+}$ and fura-2- $\mathrm{La}^{3+}$. Spectra were obtained in MOPS-containing buffer in a cuvette with $10 \mu \mathrm{M}$ fura-2. Sequential additions were made with final concentrations of first $0.9 \mathrm{mM} \mathrm{Ca}^{2+}$ (solid line) and then $10 \mu \mathrm{M} \mathrm{La}^{3+}$ (dashed line), followed by $1 \mathrm{mM} \mathrm{Mn}^{2+}$ (dotted line). $\mathrm{La}^{3+}$ additions up to $1 \mathrm{mM}$ produced an identical spectrum to that for $10 \mu \mathrm{M} \mathrm{La}^{3+}$.
TABLE 1. Maximum and minimum fluorescence ratios (340-to-380 $\mathrm{nm}$ excitation)

\begin{tabular}{lccccc}
\hline \hline & \multicolumn{2}{c}{ Cuvette } & & \multicolumn{2}{c}{ Cells In Situ } \\
\cline { 2 - 3 } \cline { 5 - 6 } & Control & BDM & & Adult & Neonatal \\
\hline$n$ & 18 & 2 & & 14 & 5 \\
$\mathrm{R}_{\min }$ & 0.60 & 0.94 & & 0.71 & 0.64 \\
$\mathrm{R}_{\max }, \mathrm{Ca}$ & $35.8^{*}$ & 16.6 & & \\
$\mathrm{R}_{\max }, \mathrm{La}$ & 82.4 & & & 4.41 & 4.92 \\
\hline
\end{tabular}

Cuvette values were derived from excitation spectra as shown in Fig. 2. Values for cells were derived from in situ calibration experiments as described in the text. Excitation bandwidth was $3.6 \mathrm{~nm}$. Emission was $505 \pm 3.6 \mathrm{~nm}$ for cuvettes and $500 \pm 5 \mathrm{~nm}$ for cells. R, fluorescence ratio. ${ }^{*} n=4$.

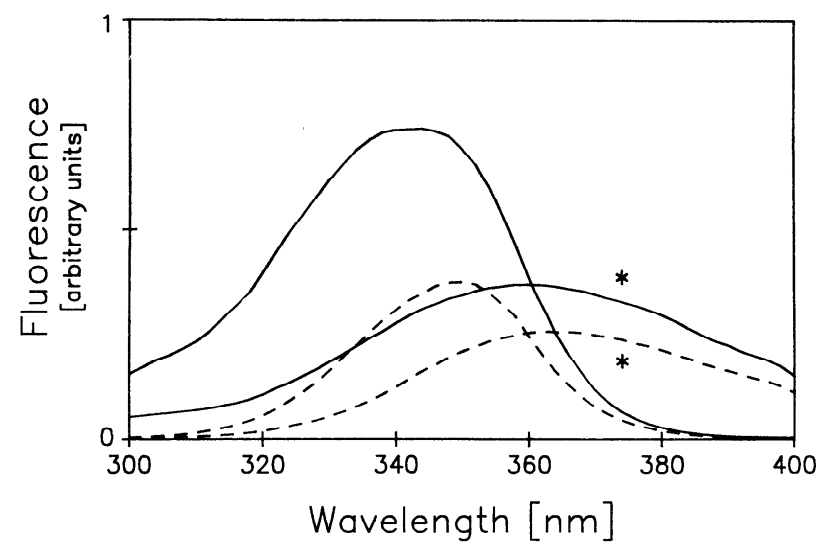

FIG. 2. Fura-2-Ca ${ }^{2+}$ spectra with and without BDM. Spectra were obtained before (solid lines) and after (broken lines) addition of $40 \mathrm{mM}$ BDM to cuvette containing MOPS buffer and $10 \mu \mathrm{M}$ fura-2. For both conditions, spectra with larger peaks were obtained with addition of 1 $\mathrm{mM} \mathrm{Ca}{ }^{2+}$, and spectra with smaller peaks and marked $\left(^{*}\right)$ were obtained after the addition of $1 \mathrm{mM}$ EG'TA.

than fura-2-Ca ${ }^{2+}$ spectra. Solving Eq. 2, the first derived constant $\left(C_{1}\right)$ relating the ratio $\left(\mathrm{R}_{\max }\right)$ of $\mathrm{Ca}^{2+}$ - to $\mathrm{La}^{3+}$ saturated fluorescence is $0.434 \pm 0.033(n=4)$. $C_{2}$ was similarly determined from fluorescence at $380 \mathrm{~nm}$ in the presence of saturating $\mathrm{Ca}^{2+}$ and $\mathrm{La}^{3+}$ and found to be $1.99 \pm 0.09(n=4)$.

The effect of BDM, a compound that uncouples myocyte excitation and contraction, on fura- $2-\mathrm{Ca}^{2+}$ spectra is shown in Fig. 2. Under both $\mathrm{Ca}^{2+}$-saturated and $0 \mathrm{Ca}^{2+}$ conditions, BDM decreased fluorescence intensity and, under $\mathrm{Ca}^{2+}$-saturated conditions, shifted peak fluorescence from 340 to $350 \mathrm{~nm}$. BDM had little effect on the isosbestic point of fura-2-Ca ${ }^{2+}$ spectra (362 $\mathrm{nm}$ before and $360 \mathrm{~nm}$ after BDM addition). To determine whether the decrease in fluorescence intensity caused by BDM is uniform regardless of whether fura-2 is bound to $\mathrm{Ca}^{2+}$ or free, the 340-to-380 $\mathrm{nm}$ ratios for the spectra in Fig. 2 are displayed in Table 1. BDM decreased the 340-to-380 $\mathrm{nm}$ ratio to varying degrees as the concentration of $\mathrm{Ca}^{2+}$ and therefore degree of fura-2-Ca ${ }^{2+}$ binding changed.

In situ calibration of fura-2 fluorescence in adult myocytes. Calibration of fura-2 fluorescence within adult myocytes was performed using the three methods designed to prevent hypercontracture as outlined above. Fura-2 fluorescence was first calibrated using BDM to prevent cellular shortening (Fig. $3 A$ ). With the onset of BDM superfusion, both $340-$ and $380-\mathrm{nm}$ signals fell in intensity, representing parallel changes in fluorescence 

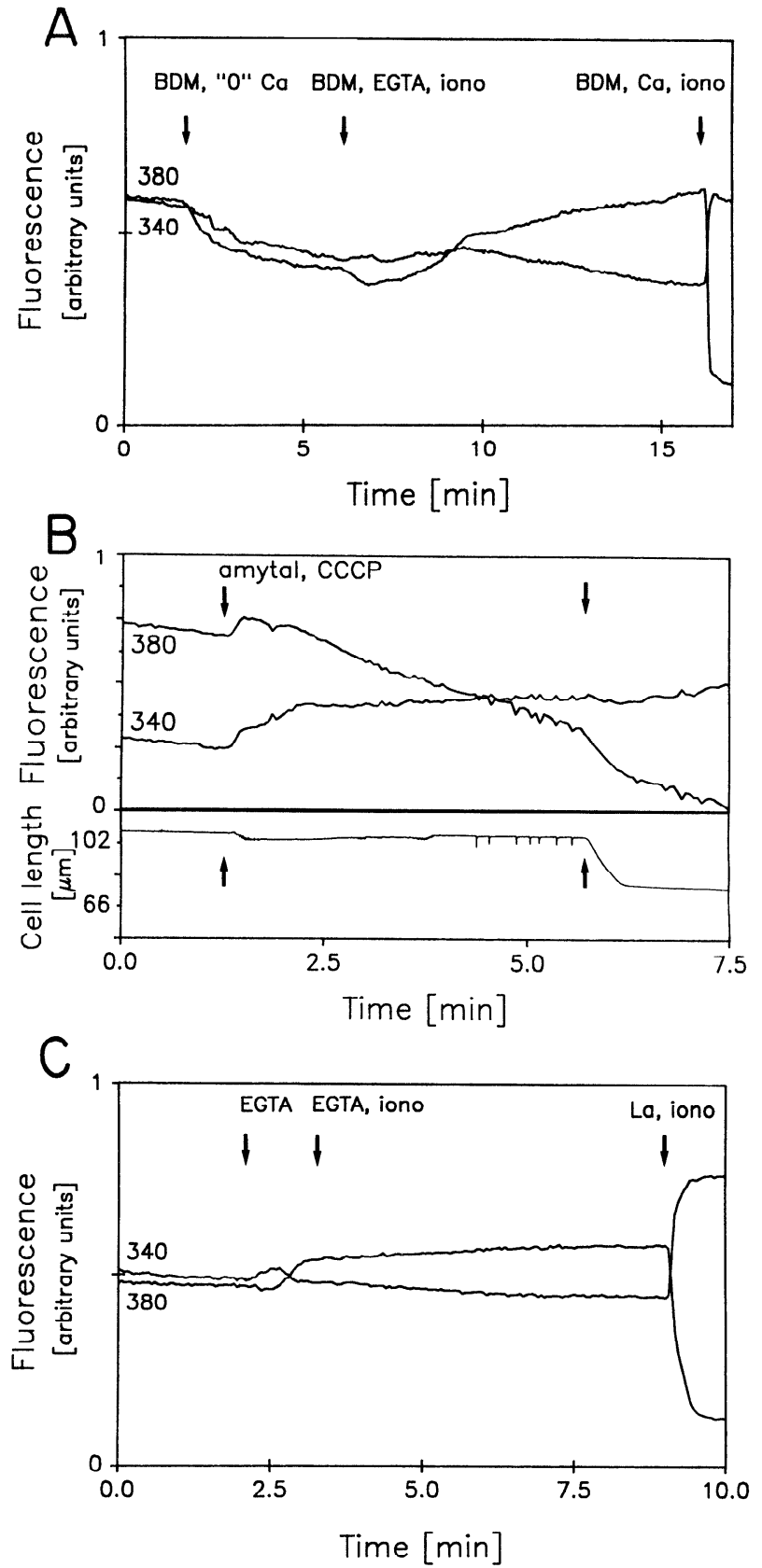

FIG. 3. Calibration of fura-2 fluorescence from adult ventricular myocytes. Fluorescence at $500 \pm 5 \mathrm{~nm}$ is shown for excitation at 340 and $380 \mathrm{~nm}$ (3.6-nm bandwidth). Background autofluorescence of cover slip and optical system has been subtracted. Changes in superfusion buffer were made as indicated at arrows. $A$ : calibration using BDM method. Cell length was unchanged throughout the course of the experiment. $B$ : calibration using "deenergization" scheme showing fluorescence signals $(t o p)$ and length measurement recorded simultaneous (bottom). At 2 nd arrow, cell was observed to shorten to $61 \%$ of its resting length. $\mathrm{C}$ : calibration using $\mathrm{La}^{3+}$ method is shown for a typical cell. Cell length was unchanged throughout experiment.

that were independent of $\left[\mathrm{Ca}^{2+}\right]_{\mathrm{i}}$. After the decrease in both signals, subsequent superfusion with BDM-containing buffers with EGTA-ionomycin and $\mathrm{Ca}^{2+}$-ionomycin produced changes directionally opposite in 340- and 380$\mathrm{nm}$ signals and were therefore likely to represent changes in $\left[\mathrm{Ca}^{2+}\right]$.

For comparison, intracellular fura-2 fluorescence was calibrated with the deenergization method of $\mathrm{Li}$ et al.
(18) (Fig. 3B). $\left[\mathrm{Ca}^{2+}\right]_{\mathrm{i}}$-independent changes were seen when the $340-$ and $380-\mathrm{nm}$ signals rose together (1st arrows) with the onset of amobarbital-CCCP superfusion. The cell then shortened slightly as the $380-\mathrm{nm}$ signal fell and 340-nm signal rose, consistent with rising $\left[\mathrm{Ca}^{2+}\right]_{\mathrm{i}}$. A second $\left[\mathrm{Ca}^{2+}\right]$-independent change was seen when the cell shortened to the square form (Fig. 3B, 2nd arrows); the 380 -nm signal dipped slightly before it continued to rise, and the $340-\mathrm{nm}$ signal fell rapidly.

The effect of the $\mathrm{La}^{3+}$ calibration method was examined for $\left[\mathrm{Ca}^{2+}\right]$-independent changes in the fura-2 signal. When fura-2 fluorescence was calibrated using $\mathrm{La}^{3+}$ (Fig. $3 C$ ), the 340- and 380-nm fluorescence signals changed simultaneously and in opposite directions when cells were subjected to the buffers designed to change the degree of $\mathrm{Ca}^{2+}$ or $\mathrm{La}^{3+}$ binding to the fura-2 present in the cytosol. No parallel $\left[\mathrm{Ca}^{2+}\right]$-independent changes in the two signals were seen. When the minimum and maximum ratios (Table 1) were used with Eqs. 1-3, $\left[\mathrm{Ca}^{2+}\right]_{\mathrm{i}}$ in 14 cells was found to be $131 \pm 47 \mathrm{nM}$.

To determine whether exposure to the calibration buffers changed cellular autofluorescence, control experiments in cells not loaded with fura-2 and subjected to the same sequence of calibration buffers were performed. Flat signals in both $340-$ and $380-\mathrm{nm}$ channels with $<5 \%$ variation in fluorescence intensity throughout the course of the experiment were observed. Other control experiments in fura-2-loaded cells superfused with standard superfusion buffer rather than the calibration solutions showed 340- and 380-nm fluorescence to decline slightly over time required for calibration (about $12 \mathrm{~min}$ ) without appreciable change in the 340 -to-380-nm fluorescence ratio.

In situ calibration of fura-2 fluorescence in cultured neonatal myocytes. Fura-2 fluorescence was calibrated in cultured neonatal cells using first $\mathrm{Ca}^{2+}$ - and then $\mathrm{La}^{3+}$ containing buffers in sequence in an attempt to verify the accuracy of the $\mathrm{La}^{3+}$-calibration constants $C_{1}$ and $C_{2}$ that were determined in the cuvette (above and Fig. 1). Perhaps because of their firmer attachment, neonatal cells exposed to high $\left[\mathrm{Ca}^{2+}\right]_{\mathrm{i}}$ do not hypercontract as readily as adult myocytes. Figure 4 and Table 1 show the results of calibration in neonatal cells exposed to EGTA followed by $\mathrm{Ca}^{2+}$ and then $\mathrm{La}^{3+}$. This protocol allowed calculation of $\left[\mathrm{Ca}^{2+}\right]_{\mathrm{i}}$ in two ways, using only Eq. 1 and $\mathrm{Ca}^{2+}$-saturated fluorescence for determination of $\mathrm{R}_{\text {max,Ca }}$ and using Eqs. 1-3 plus constants $C_{1}$ and $C_{2}$ and $\mathrm{La}^{3+}$ saturated fluorescence for determination of $R_{\text {max,La. }}$ In these cells stimulated at $1 \mathrm{~Hz}$ (Fig. 4), the time-averaged values for $\left[\mathrm{Ca}^{2+}\right]_{\mathrm{i}}$ were $500 \mathrm{nM}$ using $\mathrm{Ca}^{2+}$-saturated fluorescence for $\mathrm{R}_{\max }$ and $520 \mathrm{nM}$ using $\mathrm{La}^{3+}$-saturated fluorescence plus $C_{1}$ and $C_{2}$. In five experiments, calibration with $\mathrm{Ca}^{2+}$-saturated fluorescence yielded $417 \pm 116$ $\mathrm{nM}$, and calibration with $\mathrm{La}^{3+}$-saturated fluorescence yielded $406 \pm 90 \mathrm{nM}(F=0.03, P=0.871)$ for timeaveraged $\left[\mathrm{Ca}^{2+}\right]_{\mathrm{i}}$ in cells stimulated at $1 \mathrm{~Hz}$.

$\left[\mathrm{Ca}^{2+}\right]_{i}$ transients in adult ventricular myocytes. $\left[\mathrm{Ca}^{2+}\right]_{\mathrm{i}}$ transients were recorded from a fura-2-loaded myocyte stimulated at $1 \mathrm{~Hz}$ and calibrated by the $\mathrm{La}^{3+}$ method (Fig. 5). In this representative cell, systolic $\left[\mathrm{Ca}^{2+}\right]_{\mathrm{i}}$ averaged over eight beats was $911 \pm 86 \mathrm{nM}$ and 


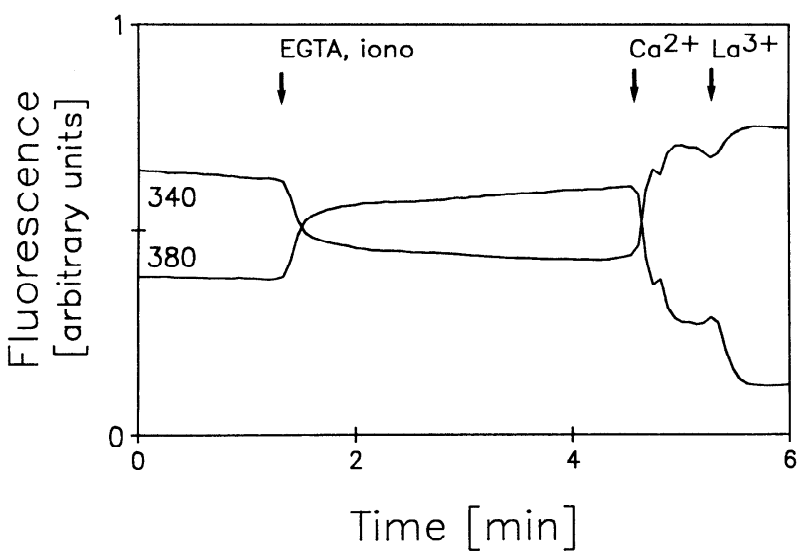

FIG. 4. Calibration of fura-2 fluorescence in cultured neonatal ventricular myocytes. Fura-2 fluorescence was collected under identical conditions as those shown in Fig. 3. Calibration was performed by sequential superfusion with ionomycin-containing buffers and either EGTA, $\mathrm{Ca}^{2+}$, or $\mathrm{La}^{3+}$.

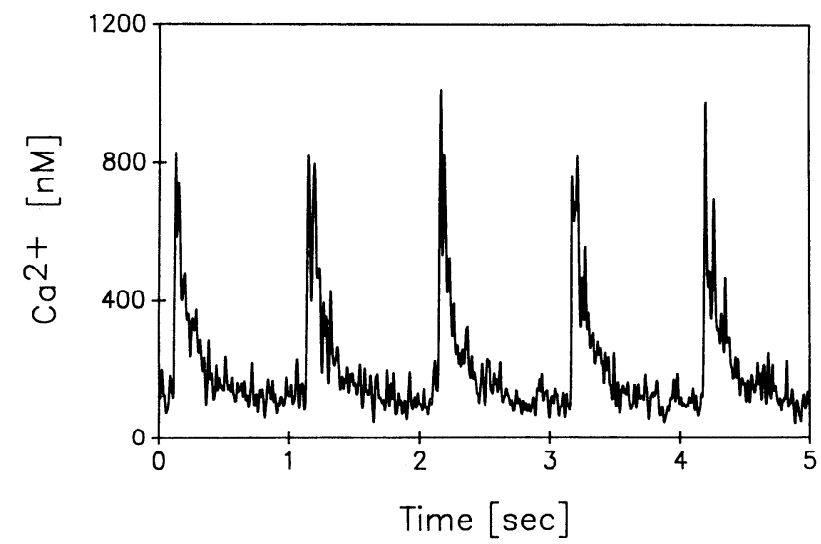

FIG. 5. $\mathrm{Ca}^{2+}$ transients recorded from a fura-2-loaded myocyte stimulated at $1 \mathrm{~Hz}$. Fluorescence at $500 \pm 5 \mathrm{~nm}$ was collected from 340 and 380-nm excitation at 3-ms intervals and calibrated in situ using $\mathrm{La}^{31}$ method. After background subtraction, fluorescence ratio was converted to $\left[\mathrm{Ca}^{2+}\right]_{\mathrm{i}}$, filtered at $100 \mathrm{~Hz}$, and plotted with $\left[\mathrm{Ca}^{2+}\right]_{\mathrm{i}}$ as ordinate.

end-diastolic $\left[\mathrm{Ca}^{2+}\right]_{\mathrm{i}}$ was $108 \pm 8 \mathrm{nM}$. In five cells identically calibrated, the mean systolic $\left[\mathrm{Ca}^{2+}\right]_{\mathrm{i}}$ was $1,088 \pm$ $211 \mathrm{nM}$ and end-diastolic $\left[\mathrm{Ca}^{2+}\right]_{\mathrm{i}}$ was $140 \pm 56 \mathrm{nM}$.

In situ calibration of BCECF fluorescence in adult ventricular myocytes. BCECF fluorescence was calibrated within BCECF-loaded myocytes. For the cell shown in Fig. 6, in response to $10 \mathrm{mM} \mathrm{NH}_{4} \mathrm{Cl}, \mathrm{pH}_{\mathrm{i}}$ rose from 7.02 to 7.33 , and upon washout, $\mathrm{pH}_{\mathrm{i}}$ fell to 6.85 . The cell was then exposed to three calibration buffers $(\mathrm{pH} 6.54,7.27$, and 7.75), and $\mathrm{pH}_{\mathrm{i}}$ was determined as described above. External buffer $\mathrm{pH}$ was linearly related to fluorescence ratio ( $r=0.999, P=0.028$ ) over the range examined. The cell maintained its rod-shaped morphology throughout the calibration procedure. Control experiments in cells not loaded with BCECF showed absolute levels of fluorescence intensity that were $<3 \%$ of that present in loaded cells at both the 490- and 450-nm excitation. In 12 cells calibrated similarly, the $\mathrm{pH}_{\mathrm{i}}$ of cells stimulated at $1.5 \mathrm{~Hz}$ was determined to be $7.10 \pm 0.10$. We observed no hysteresis effect of external $\mathrm{pH}$ buffers on fluorescence ratio when the order of exposure to high, middle, and low $\mathrm{pH}$ calibration buffers was changed.

Dye compartmentation in adult myocytes. To assess the

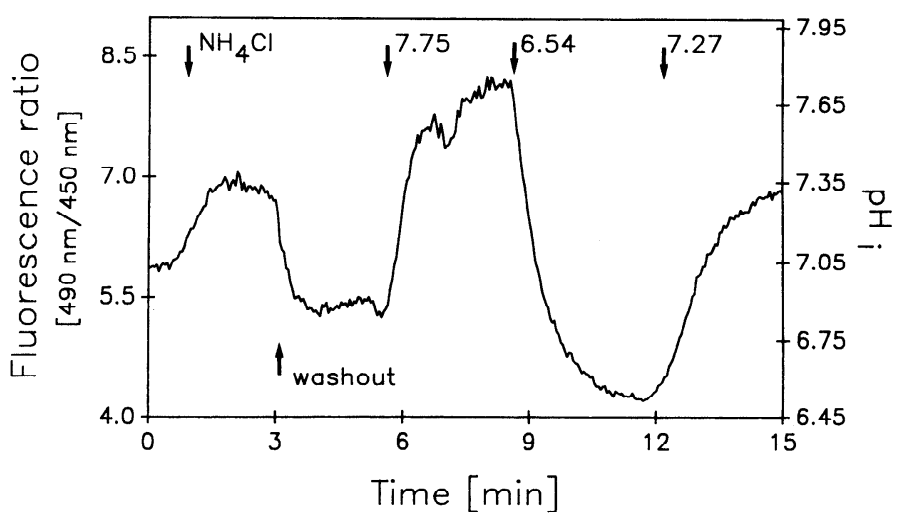

FIG. 6. Calibration of a BCECF-loaded myocyte. Fluorescence was collected at $530 \pm 10 \mathrm{~nm}$ for excitation at 490 and $450 \mathrm{~nm}$ (3.6-nm band pass); these signals were divided after background subtraction, and ratio is shown on left ordinate. Cell was exposed to $10 \mathrm{mM} \mathrm{NH}_{4} \mathrm{Cl}$ at 1 st arrow; washout occurred at 2 nd arrow. Superfusion with $3 \mathrm{pH}$ titrated calibration buffers is shown. $\mathrm{pH}$ values determined by linear regression of buffer $\mathrm{pH}$ with fluorescence ratio are shown on right ordinate.

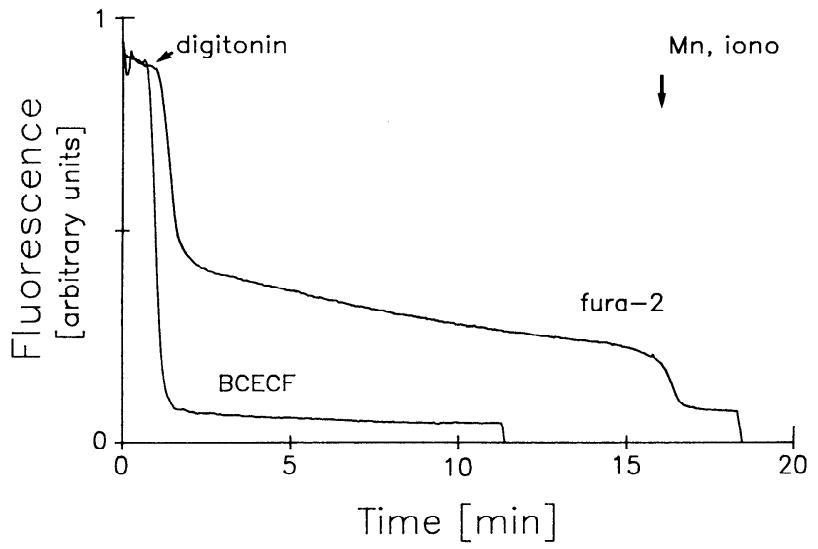

FIG. 7. Chemical skinning of fura-2- and BCECF-loaded myocytes. Separate experiments are shown for fura-2- and BCECF-loaded myocyte. Excitation is at $359 \pm 1.8 \mathrm{~nm}$ for fura-2-loaded cell and $450 \mathrm{~nm}$ $\pm 1.8 \mathrm{~nm}$ for BCECF-loaded cell. Ordinate has been scaled to show same level of fluorescence intensity at beginning of both experiments. While both cells were exposed to digitonin $(10 \mu \mathrm{M}$; see MATERIALS AND METHODS), only fura-2-loaded cell was subsequently exposed to $1 \mathrm{mM}$ $\mathrm{Mn}^{2+}$ and $10 \mu \mathrm{M}$ ionomycin. Background fluorescence has been subtracted from both recordings as determined by fluorescence of cover slip alone adjacent to cell.

extent of compartmentation of fura- 2 and BCECF within intracellular organelles, cells were chemically "skinned" by exposure to digitonin $(2,28)$. In fura-2-loaded cells, we identified three components of fluorescence after subtraction of background (Fig. 7). Fluorescence was measured with excitation wavelength of $359 \mathrm{~nm}$, which is the isobestic point for fura- 2 in ventricular cells. The first and largest component of fluorescence was released by $10 \mu \mathrm{M}$ digitonin in a biphasic manner and accounted for $70.8 \pm 3.9 \%(n=3)$ of total fluorescence. The second component was quenched by the addition of $1 \mathrm{mM} \mathrm{Mn}^{2+}$ and $10 \mu \mathrm{M}$ ionomycin and accounted for $20.8 \pm 4.7 \%$ ( $n$ $=3$ ) of fluorescence. The third component represented the difference between remaining fluorescence (presumably cellular constituents) and background (from the cover slip and system) and accounted for $8.4 \pm 1.0 \%$ ( $n$ $=3$ ) of fluorescence.

In BCECF-loaded myocytes, fluorescence measure- 
ments were made at $450 \mathrm{~nm}$, a wavelength showing little change with $\mathrm{pH}_{\mathrm{i}}$. In contrast to the release of fura-2, fluorescence in BCECF-loaded cells showed only a rapid decline after exposure to digitonin that accounted for $92.2 \pm 1.5 \%(n=3)$ of total fluorescence. A digitonininsensitive component, representing $7.8 \pm 1.5 \%(n=3)$ of total fluorescence, was the compartmentalized dye and cellular autofluorescence remaining before background subtraction.

\section{DISCUSSION}

In vitro calibration of a fluorescent dye requires the generation of a standard curve relating fluorescence intensity to the concentration of the ion studied. An important assumption is that dye behavior is identical in calibration buffers and cells (12). Even if ratio spectroscopy is used to minimize the effects of such variables as variations in path length, motion, nonuniform dye concentrations, light scattering, and variable illumination (6), buffers cannot be assumed to completely represent the intracellular environment. Moreover, studies comparing in vitro with in situ standard calibration curves in muscle fibers (14), cells (25), and isolated mitochondria (24) have shown different relationships between fluorescence ratio and ion concentrations resulting in discrepant calculations of $\left[\mathrm{Ca}^{2+}\right]_{\mathrm{i}}$ and $\mathrm{pH}_{\mathrm{i}}$. Several studies have found that properties of fura- 2 injected into muscle fibers in its salt form are not those expected from cuvette measurements with regard to diffusion (15), protein binding (15), and $\mathrm{Ca}^{2+}$ association and dissociation rates (14). Similarly, when fura-2 was loaded into cells in its AM form, its fluorescence was not reliably described by in vitro calibration buffers $(10,18)$, but $\left[\mathrm{Ca}^{2+}\right]_{\mathrm{i}}$ could be calculated if calibration was accomplished in situ $(21,25)$.

In situ calibration of fura-2 fluorescence. Several in situ calibration methods have been proposed to avoid the hypercontracture problem unique to adult ventricular cells. One method employs BDM, an agent that purportedly uncouples excitation from contraction by direct interaction with actin and myosin. Cheung et al. (9) have reported that $\mathrm{BDM}$ allowed saturation of fura- 2 by $\mathrm{Ca}^{2+}$ while rat ventricular cells were maintained in their rod shape. However, we found that BDM altered spectral properties of fura- 2 by both attenuating the fluorescence signal and red shifting the peak excitation wavelength (Fig. 2, Table 1), possibly by the inner filter effect (17), and produced $\left[\mathrm{Ca}^{2+}\right]_{\mathrm{i}}$-independent changes in cellular fluorescence (Fig. $3 A$ ). In the report of Cheung et al. (9), fluorescence during calibration was measured intermittently by digital imaging rather than continuously by photon counting as in our system, so the $\left[\mathrm{Ca}^{2+}\right]$-independent changes may have been missed.

A second method of preventing hypercontracture during in situ calibration was described by $\mathrm{Li}$ et al. (18). This method involves exposure of the cell to a deenergizing combination of amobarbital and CCCP to produce a partial square form of hypercontracture that is resistant to further shortening into the round form, thereby permitting determination of $\mathrm{Ca}^{2+}$-saturated fura-2 fluorescence. However, we found that this protocol changed fura-2 fluorescence in a $\left[\mathrm{Ca}^{2+}\right]_{\mathrm{i}}$-independent manner (Fig. $3 B$ ), both with the onset of superfusion with amobarbital and CCCP and after $\sim 5 \mathrm{~min}$, when the cell shortened.

Fura- $\mathrm{La}^{3+}$ fluorescence properties. The present study has demonstrated that the affinity of $\mathrm{La}^{3+}$ for fura- 2 was higher than that of $\mathrm{Ca}^{2+}$ (Fig. 1), since $\mathrm{La}^{3+}$-saturated fura-2 fluorescence did not increase for concentrations of $\mathrm{La}^{3+}>10 \mu \mathrm{M}$, the same concentration as fura-2 present in the cuvette (Fig. 1), whereas, for $\mathrm{Ca}^{2+}$, concentrations of the cation far in excess of the fluorophore were required. Furthermore, although $\mathrm{Mn}^{2+}$ showed a 42 -fold preference over $\mathrm{Ca}^{2+}$ for fura-2 and quenched its fluorescence (12), Fig. 1 shows that $\mathrm{Mn}^{2+}$ quenched only $25 \%$ of fura-2 fluorescence when present in 10-fold greater concentration than $\mathrm{La}^{3+}$, suggesting that fura-2 had a greater affinity for $\mathrm{La}^{3+}$ than $\mathrm{Mn}^{2+}$. If comparable properties are assumed for fura- 2 and indo- 1 , these findings are in agreement with those of Peeters et al. (22).

In situ calibration with the $\mathrm{La}^{3+}$ method. After finding that in situ calibration with the $\mathrm{La}^{3+}$ method prevented hypercontracture and avoided the $\left[\mathrm{Ca}^{2+}\right]$-independent changes seen with other methods (Fig. 3), the applicability of the calibration factors to the intracellular environment was confirmed in neonatal ventricular myocytes, which are resistant to hypercontracture (Fig. 4). When $\left[\mathrm{Ca}^{2+}\right]_{\mathrm{i}}$ was calculated with the $\mathrm{La}^{3+}$ method in neonatal myocytes, the results were quite similar to $\left[\mathrm{Ca}^{2+}\right]_{\mathrm{i}}$ calculated by standard methods $(12,25)$ in the same cells using $\mathrm{Ca}^{2+}$ as the saturating cation: $406 \pm 90 \mathrm{nM}$ for $\mathrm{La}^{3+}$ and $417 \pm 116 \mathrm{nM}$ for $\mathrm{Ca}^{2+}$. Although differences may exist in the intracellular environment, $\mathrm{La}^{3+}$ calibration in adult cells should be similar to neonatal myocytes, since the $\mathrm{La}^{3+}$-saturated fluorescence ratio was comparable in both cell types (Table 1). Maximum fluorescence ratios in situ were lower than cuvette measurements in part because glass cover slips attenuated light at $340 \mathrm{~nm}$ and in part because of alterations of dye properties in the intracellular environment (9).

Values for $\left[\mathrm{Ca}^{2+}\right]_{i}$ using the $\mathrm{La}^{3+}$ calibration method. The $\left[\mathrm{Ca}^{2+}\right]_{\mathrm{i}}$ values of $131 \mathrm{nM}$ in quiescent cells and in cells stimulated at $1 \mathrm{~Hz}, 1,088 \mathrm{nM}$ systolic/140 nM diastolic, are compared with values for adult rat ventricular cells reported by other investigators (Table 2). Our measurements yielded values that are concordant with $\left[\mathrm{Ca}^{2+}\right]_{\mathrm{i}}$ determined by a variety of other approaches. However, the $\mathrm{La}^{3+}$ calibration method relies on a value for the fura-2- $\mathrm{Ca}^{2+}$ equilibrium constant that was experimentally determined under in vitro conditions $(9,12)$. Since the net effect of myoplasm on the equilibrium constant in our system at $37^{\circ} \mathrm{C}$ cannot be determined due to progressive shortening of the cell as $\left[\mathrm{Ca}^{2+}\right]_{i}$ is raised, the calculated values for $\left[\mathrm{Ca}^{2+}\right]_{i}$ we report may be in error to the extent that the value used for $K_{\mathrm{d}}, 224 \mathrm{nM}$, is incorrect.

Intracellular dye compartmentation. A problem with any study in which fluorescent probes are loaded into a cell by the widely used approach of introducing dye into cells by diffusion of its AM form is intracellular compartmentation. The $\mathrm{La}^{3+}$ technique can be used in myocytes injected with the salt form of dye, with which 
TABLE 2. Comparisons of $\left[\mathrm{Ca}^{2+}\right]_{i}$ measurements in isolated adult rat ventricular cells

\begin{tabular}{|c|c|c|c|c|}
\hline $\begin{array}{l}\text { Ref. } \\
\text { No. }\end{array}$ & $\begin{array}{l}\text { Cell } \\
\text { Type }\end{array}$ & $\begin{array}{c}\text { Calibration } \\
\text { Method }\end{array}$ & $\begin{array}{l}\text { Quiescent } \\
{\left[\mathrm{Ca}^{2+}\right]_{i}, \mathrm{nM}}\end{array}$ & $\begin{array}{c}\text { Systolic } \\
{\left[\mathrm{Ca}^{2+}\right]_{i}, \mathrm{nM}}\end{array}$ \\
\hline \multicolumn{5}{|c|}{ Fura-2 } \\
\hline 3 & Single & In vitro & $\sim 75$ & 500 \\
\hline 7 & Single & In vitro & $90 \pm 6$ & $213 \pm 23$ \\
\hline 8 & Single & In vitro & $\sim 100$ & $\sim 1,000$ \\
\hline 9 & Single & In vitro & $90 \pm 6$ & \\
\hline 10 & Single & In vitro & $93 \pm 12$ & \\
\hline 18 & Single & In situ & $112 \pm 14$ & \\
\hline 19 & Single & In situ & $125(70 \quad 200)$ & \\
\hline 31 & Single & In vitro & $134 \pm 43$ & \\
\hline \multicolumn{5}{|c|}{$\begin{array}{l}\text { In situ } \\
\text { Indo- } 1\end{array}$} \\
\hline 13 & Suspension & $\begin{array}{c}\text { In vivo } \\
\text { Quin }\end{array}$ & $247 \pm 16$ & \\
\hline 23 & Suspension & In vivo & $137 \pm 3$ & \\
\hline \multicolumn{4}{|c|}{ Aequorin } & \\
\hline 1 & Single & In vivo & $195 \pm 8(145-259)$ & \\
\hline 27 & Single & In vivo & $\sim 250$ & \\
\hline
\end{tabular}

Values for $\left[\mathrm{Ca}^{2+}\right]_{\mathrm{i}}$ are means $\pm \mathrm{SD}$ with ranges in parentheses. In vitro refers to calibration by $\mathrm{Ca}^{2+}$-EGTA buffers and in situ to calibration within an individual cell or suspension. For details see text.

compartmentation would not likely be a problem.

Releasing cytosolic contents with low concentrations of digitonin is well established in cardiac myocytes (2, $11,28)$. Dye remaining after digitonin treatment presumably represents dye sequestered predominantly in mitochondria; this organelle was found by other investigators to be the site of sequestration of $\mathrm{Ca}^{2+}$-sensitive dyes in adult myocytes (28) and in neonatal rat ventricular cells viewed by digital imaging $(11,29)$. Spurgeon et al. (28) recently showed that in indo-1-loaded myocytes, a digitonin treatment similar to ours released $82 \%$ of lactate dehydrogenase, whereas $98 \%$ of citrate synthase remained. This suggests that digitonin acts selectively on the sarcolemma and that an estimate of mitochondrial dye is conservative, since $18 \%$ of cytosolic contents presumably remains after digitonin.

Because fluorescence from mitochondria would not be expected to oscillate with systole and diastole, this contribution to the fluorescent signal would tend to dampen the maximum and minimum fluorescence attributable to $\mathrm{Ca}^{2+}$ interacting with cytosolic fura-2 throughout the cardiac cycle. The values that we report for $\left[\mathrm{Ca}^{2+}\right]_{\mathrm{i}}$ in ventricular myocytes may therefore underrepresent systolic $\left[\mathrm{Ca}^{2+}\right]_{\mathrm{i}}$ and may underestimate or overestimate diastolic and resting $\left[\mathrm{Ca}^{2+}\right]_{\mathrm{i}}$, depending on the degree to which $\left[\mathrm{Ca}^{2+}\right]$ in organelles differs from cytoplasm. Nevertheless, introduction of fura-2 in the AM form to estimate $\left[\mathrm{Ca}^{2+}\right]_{i}$ remains a valid approach, subject to these quantitative considerations.

Our estimates of systolic $\left[\mathrm{Ca}^{2+}\right]_{\mathrm{i}}$ may misrepresent the actual value for two other reasons. First, $\left[\mathrm{Ca}^{2+}\right]_{\mathrm{i}}$ transients have been filtered at $100 \mathrm{~Hz}$, which dampened the peak systolic values of $\left[\mathrm{Ca}^{2+}\right]_{\mathrm{i}}$ slightly. Second, the kinetics of the fura- 2 and $\mathrm{Ca}^{2+}$ interaction are not precisely known and may not sufficiently resolve the rapid release and reuptake of $\mathrm{Ca}^{2+}$ during a twitch (15).

Another concern with the use of AM forms of dye for loading into cells is the problem of $\mathrm{Ca}^{2+}$-insensitive but fluorescent species of partly hydrolyzed dye. Our approach to account for the possible presence of these forms in myocytes has been to employ in situ calibration. An early report using indo- 1 in endothelial cells showed that ratio spectroscopy failed to correct for partly hydrolyzed indo-1/AM and gave erroneous $\left[\mathrm{Ca}^{2+}\right]_{\mathrm{i}}$ values $(20)$ in cells loaded for $90 \mathrm{~min}$ at $37^{\circ} \mathrm{C}$. However, more recent reports have suggested that the combination of shorter loading times at room temperature (21), plus in situ calibration (25), can account for partly hydrolyzed fluorescent dye forms and yield correct $\left[\mathrm{Ca}^{2+}\right]_{i}$ values.

Calibration of BCECF fluorescence in ventricular cells. The method described in this report for calibration of BCECF fluorescence avoided hypercontracture of the cell. NADH fluorescence has less overlap with BCECF than with fura-2 and most likely did not contribute substantially to total fluorescence. In BCECF-loaded cells, the fluorescence ratio was found to be linearly related to $\mathrm{pH}_{\mathrm{i}}$ in the range studied (Fig. 6 and Ref. 9). The value of 7.10 in myocytes stimulated at $1.5 \mathrm{~Hz}$ in HEPES-buffered medium is slightly lower than the values of 7.16 determined in single rat ventricular cells (11) and 7.16 in ventricular cells in suspension (30). Neither of these studies reported mean $\mathrm{pH}_{\mathrm{i}}$ values for contracting myocytes, an energy-requiring process which has been reported to reversibly lower the $\mathrm{pH}$ of isolated Purkinje fibers (5). Furthermore, in the former report (11) shape change was not discussed, and in the latter, an in vitro calibration curve was used and the contribution of dead or rounded cells to average $\mathrm{pH}_{\mathrm{i}}$ was not determined (30).

With our method of loading BCECF into ventricular cells, $>92 \%$ of fluorescence is released by digitonin (Fig. 7) and therefore appears to arise from cytoplasmic $\mathrm{BCECF}$, making the potential error in $\mathrm{pH}_{\mathrm{i}}$ measurement due to compartmentation relatively small.

Summary and conclusions. The methods reported in this study for calibrating fura-2 and BCECF fluorescence in adult ventricular cells allow for reproducible in situ calibration of the fluorescence signal and avoid several pitfalls encountered with other calibration methods. The use of $\mathrm{La}^{3+}$ for fura-2 fluorescence calibration is a novel technique permitting in situ calibration of fura- 2 in individual myocytes while limiting changes in $\mathrm{Ca}^{2+}$-independent fluorescence caused by hypercontracture and pyridine nucleotides. With this technique, a valid estimate of $\left[\mathrm{Ca}^{2+}\right]_{\mathrm{i}}$ can therefore be made both in cells loaded with fura-2/AM and in cells injected with the fura-2 dye salt as well.

We thank Mary O'Neill and Stephanie Murphy for excellent technical assistance, Thomas W. Smith MD for advice and support, and Paula McColgan for typing the manuscript.

This study was supported in part by National Heart, Lung, and Blood Institute Grants HL-35781, HL-26215, and HL-36141 and grants from Paul-Martini-Stiftung, Bonn, FRG (to B. K. Kramer), the American Heart Association, Massachusetts Affiliate (to Y. Matoba), and the Pharmaceutical Manufacturers Association (to R. A. Kelly).

Address for reprint requests: M. Reers, Cardiology Div., Brigham and Women's Hospital, 75 Francis St., Boston, MA 02115.

Received 2 November 1989; accepted in final form 24 April 1990. 


\section{REFERENCES}

1. Allshire, A., H. M. Piper, K. S. R. Cuthbertson, and P. H. CoBBoLd. Cytosolic free $\mathrm{Ca}^{2+}$ in single rat heart cells during anoxia and reoxygenation. Biochem. J. 244: 381-385,1987.

2. Altschuld, R. A., W. C. Wenger, K. G. Lamka, O. R. Kindig, C. C. Capfin, V. Mizuhira, R. S. Vander Heide, and G. P. BrIERLY. Structural and functional properties of adult rat heart myocytes lysed with digitonin. J. Biol. Chem. 260: 14325-14334, 1985.

3. Beirlin, J. R., M. B. Cannell, and W. J. Lejoerer. Cellular origins of the transient inward current in cardiac myocytes: role of fluctuations and waves of elevated intracellular calcium. Circ. Res. 65: 115-126, 1989.

1. Bloch, K. D., J. G. Seidman, J. D. Naftilan, J. T. Fallon, and C. F. Seidman. Neonatal atria and ventricles secrete atrial natriuretic factor via tissue-specific secretory pathways. Cell 47: 695$702,1986$.

5. Bountra, C., K. Kalia, and R. D. Vaughn-Jones. Effect of repetitive activity upon intracellular $\mathrm{pH}$, sodium and contraction in sheep cardiac Purkinje fibers. J. Physiol. Lond. 398: 341-360, 1988 .

6. Bright, G. R., G. W. Fisher, J. Rogowska, and D. L. Taylor. Fluorescence ratio imaging microscopy: temporal and spatial measurements of cytoplasmic pH. J. Cell Biol. 98: 717-724, 1984.

7. Callewaert, G., L. Cleeman, and M. Morad. Epinephrine enhances $\mathrm{Ca}^{2+}$ current-regulated $\mathrm{Ca}^{2+}$ release and $\mathrm{Ca}^{2+}$ reuptake in rat ventricular myocytes. Proc. Natl. Acad. Sci. USA 85: 20092013, 1988.

8. Cannell, M. B., J. R. Berlin, and W. J. Lederer. Effect of membrane potential changes on the calcium transient in single rat cardiac muscle cells. Science Wash. DC 238: 1419-1423, 1987.

9. Cheung, J. Y., D. L. Tillotson, R. V. Yelamarty, and R. C. SCADUTO, JR. Cytosolic free calcium in individual cardiac myocytes in primary culture. Am. J. Physiol. 256 (Cell Physiol. 25): C1120C1130, 1989

10. Eisner, D. A., C. G. Nichols, S. C. O’Neill, G. L. Smith, And M. VALDEOLMILlos. The effects of metabolic inhibition on intracellular calcium and $\mathrm{pH}$ in isolated rat ventricular cells. J. Physiol. Lond. 411: 393-418, 1989.

11. Gores, G. J., A.-L. Nieminen, J. M. Bond, B. Herman, and J. J. Lemasters. Subcellular compartmentation of fura-2 and BCECF loaded as acetoxymethyl esters into hepatocytes and myocytes (Abstract). Int. Conf. Video Microsc. Chapel Hill NC 1989.

12. Grynkiewicz, G., M. Poenie, and R. Y. Tsien. A new generation of $\mathrm{Ca}^{2+}$ indicators with greatly improved fluorescence properties. J. Biol. Chem. 260: 3440-3450, 1985.

13. Haworth, R. A., A. B. Goknur, D. R. Hunter, J. O. Hegge, AND H. A. BERKOFF. Inhibition of calcium influx in isolated adult rat heart cells by ATP depletion. Circ. Res. 60: 586-594, 1987.

14. Klein, M. G., B. J. Simon, G. Szucs, And M. F. Schneider. Simultaneous recording of calcium transients in skeletal muscle using high- and low-affinity calcium indicators. Biophys. J. 53: 971-988, 1988

15. Konishi, M., A. Olson, S. Hollingworth, and S. M. Baylor. Myoplasmic binding of fura-2 investigated by steady-state fluores- cence and absorbance measurements. Biophys. J. 54: 1089-1104, 1988.

16. Koretsky, A. P., L. A. Katz, and R. S. Balaban. Determination of pyridine nucleotide fluorescence from the perfused heart using an internal standard. Am. J. Physiol. 253 (Heart Circ. Physiol. 22): H856-H862, 1987.

17. Lakowicz, J. R. Principles of Fluorescence Spectroscopy. New York: Plenum, 1983, p. 43-49.

18. Li Q., R. A. Altschuld, AND B. T. Stokes. Quantitation of intracellular free calcium in single adult cardiomyocytes by fura-2 fluorescence microscopy: calibration of fura-2 ratios. Biochem. Biophys. Res. Commun. 147: 120-126, 1987.

19. LI, Q., R. A. Altschuld, AND B. T. STokes. Myocyle deenergization and intracellular free calcium dynamics. Am. J. Physiol. 255 (Cell Physiol. 24): C162 C168, 1988.

20. Luскноғғ, A. Measuring cytosolic free calcium concentration in endothelial cells with indo-1: the pitfall of using the ratio of 2 fluorescence intensities recorded at different wavelengths. Cell Calcium 7: 233-248, 1986.

21. Malgaroli, A., D. Milani, J. Meldolesi, and T. Pozzan. Fura2 measurement of cytosolic free $\mathrm{Ca}^{2+}$ in monolayers and suspensions of various types of animal cells. J. Cell. Biol. 105: 2145-2155, 1987.

22. Peeters, G. A., O. Kohmoto, and W. H. Bakry. Detection of $\mathrm{La}^{3+}$ influx in ventricular cells by indo-1 fluorescence. Am. J. Physiol. 256 (Cell Physiol. 25): C351-C357, 1989.

23. Powell, T., P. E. R. Tatham, and V. W. Twist. Cytoplasmic free calcium measured by quin-2 fluorescence in isolated ventricular myocytes at rest and during potassium depolarization. Biochem. Biophys. Res. Commun. 122: 1012-1020, 1984.

21. Reers, M., R. A. Kelly, and T. W. Smith. Calcium and proton activities in rat cardiac mitochondria: effect of matrix environment on behavior of fluorescent probes. Biochem. J. 257: 131-142, 1989.

25. ScAnlon, M., D. A. Williams, AND F. S. FAy. A Ca ${ }^{2+}$-insensitive form of fura-2 associated with polymorphonuclear leukocytes. $J$. Biol. Chem. 262: 6308-6312, 1987.

26. Sheu, S.-S., V. K. Sharma, S. P. Banerjee. Measurement of cytosolic free calcium concentration in isolated rat ventricular myocytes with quin2. Circ. Res. 55: 830-834, 1984.

27. Snowdowne, K. W., R. J. ERTEl, ANd A. B. Borle. Measurement of cytosolic calcium with aequorin in dispersed rat ventricular cells. J. Mol. Cell. Cardiol. 17: 233-241, 1985.

28. Spurgeon, M. A., M. D. Stern, G. BaArtz, S. Raffaeli, R. L. Hansford, A. Talo, E. G. Lakatta, and M. C. Capogrossi. Simultaneous measurement of $\mathrm{Ca}^{2+}$ contraction, and potential in cardiac myocytes. Am. J. Physiol. 258 (Heart Circ. Physiol. 27): H574-H586, 1990.

29. Steinberg, S. F., J. P. Bilezikian, and Q. Al-Awqati. Fura-2 fluorescence is localized to mitochondria in endothelial cells. Am. J. Physiol. 253 (Cell Physiol. 22): C744-C747, 1987.

30. Wallert, M. A., AND O. FroHLICH. $\mathrm{Na}^{+}-\mathrm{H}^{+}$exchange in isolated myocytes from adult rat heart. Am. J. Physiol. 257 (Cell Physiol. 26): C207-C213, 1989.

31. Wier, W. G., M. B. Cannell, J. R. Berlin, E. Marban, and W. J. LEDERER. Cellular and subcellular heterogeneity of $\left[\mathrm{Ca}^{2+}\right]_{\mathrm{i}}$ in single heart cells revealed by fura-2. Science Wash. DC 235: 325328, 1987. 